\title{
Duiwelbesetenheid en Duiweluitdrywery in die lig van die Nuwe Testament
}

\author{
D J C VAN WYK
}

Die verskynsel van duiweluitdrywery het, sover skrywer hiervan se kennis strek, in die Hervormde Kerk nog baie min kop uitgesteek. Die vraag is, of hierdie feit ons behoort te vlei of dalk baie ernstig behoort te verontrus. Ek bedoel dit: Die aanwesigheid van verskynsels soos hierdie kan 'n simptoom van ernstige dwaling wees. Maar die afwesigheid van verskynsels soos hierdie in die kerk in ons tyd, is nie noodwendig ' $n$ simptoom van nugtere geloof nie. Dit kan ook'n simptoom van ernstige doodsheid, vervlakking en verwêreldliking in die geloof en lewe van die kerk wees.

In 'n poging om tot groter helderheid oor hierdie onderwerp te kom, moet ons aan die hand van ' $n$ kort behandeling van 'n paar van die betrokke gedeeltes uit die Nuwe Testament, probeer vasstel wat besetenheid was, en wat gebeur het tydens die genesing van sulke besetenes.

\section{Matteus 8:28-34; Markus 5:1-20; Lukas 8:26-39 ,}

Eerstens die genesing van die besetene van Gadara. Vir ons doel word nie ingegaan op kleiner of groter verskille tussen die verskillende evangeliste waar hulle dieselfde geskiedenis vertel nie. Dit blyk ook dat die woorde of uitdrukkings wat vir hierdie verskynsel gebruik is nie besondere lig op die saak werp nie. In Matteus 8:28 word byvoorbeeld ' $n$ woord gebruik wat in die nuwe Afrikaanse Bybel vertaal word met "in die mag van duiwels." In Markus 5:2 word gebruik gemaak van 'n uitdrukking, wat in die nuwe Afrikaanse vertaling weergegee word as "'n man met 'n onreine gees." In Lukas 8:27 word gesê: (volgens die nuwe Afrikaanse vertaling) "hy was van duiwels besete." Dieselfde uitdrukking vertaal die nuwe Afrikaanse vertaling in Markus 1:23 egter met "'n man wat van 'n onrein gees besete was." Ook plekke soos Lukas 4:33, in Afrikaans vertaal met "'n man wat in die mag was van 'n duiwel, 'n onrein gees", en Lukas 11:14, werp, wat taalgebruik betref, nie besondere lig op die saak nie.

Die genesing van die besetene van Gadara is van die mees dramatiese genesingsgeskiedenisse in die Nuwe Testament. Die hoof- 
stukke is vol van die spanning tussen die openbaring van die ryk van Christus wat kom, maar nog nie geheel in die wêreld deurgebreek het nie, en die ryk van die demone, wie se lot reeds beseël is, maar wat ' $n$ verbete en hopelose stryd voer om hulle in die wêreld te handhaaf. Die land van die Gadareners se bevolking was heidens. Dit klink eintlik of die hele streek deur swaar onreinheid geteister word. Daar is volop sprake van besetenes, grafte en varke. Die onreine skreeu vir Jesus: Het jy hierheen gekom om ons voor die tyd te pynig? Die woord "pynig", hoort in 'n apokaliptiese sfeer tuis. Die wêreld, wat deur hierdie besetene verteenwoordig word, weet dat sy einde in aantog is. Hy veg tot die uiterste om sy bestaan te rek. Dit is geweldige ironie wat uit hierdie verbitterde stryd opklink.

Christus het gekom om die werke van die duiwel te verbreek. Die versoeking in die woestyn het voortgang in die evangelie. Hier het ons ' $n$ moment in die voortgaande botsing tussen Jesus en die vader van die leuens. Die duiwels ken Jesus. Hulle glo in Hom, maar sidder. Hulle bely Hom ook as Christus maar vra uitstel van die oordeel.

As Jesus die besetene se naam vra, kom die antwoord in die meervoud. Vele geeste antwoord dat hulle eintlik 'n legioen vorm. Hieruit blyk nie net ' $n$ diepe rampsaligheid wat nie in een naam uitgespreek kan word nie, maar ook deurtrapte arglistigheid. Legioen is geen naam nie. Met die noem van die naam sou enige besweerder kon poog om die demoon uit te dryf. 'n Legioen was 'n Romeinse leërafdeling van minstens $6000 \mathrm{man}$. Hierdie mens is so gewoond om hom met die skare van bose geeste wat in hom woon en uit hom spreek en raas te vereenselwig, dat hy van homself in die enkel- en meervoud deurmekaar praat. Hierdie mens doen wat enige normale mens juis sal vermy. Hy vertoef dag en nag in onreine grafspelonke-spookplekke.

Al wat die maatskappy van alle tye kon aanwend om 'n geweldenaar soos hierdie te tem, was geweld. Selfs dit help egter nie, sodat almal nou die plek vermy het. Nou betree Jesus die domein wat hierdie mens vir homself hier verower het. Selfs voor hierdie somberste van alle menslike rampsaligheid deins Jesus nie terug nie. Met ernstige sekerheid spreek Hy tot hierdie karikatuur van menslike wese. Die episode met die varke volg as teken vir hierdie man, wat homself oor jare heen leer een voel het met duisende demone, dat die demone werklik uitgedryf is. ' $n$ Jood mag nie bid, selfs nie eens net in die nabyheid van varke nie. Nóg die besetene, nóg die varke, kan Jesus egter verhinder om hier te kom bid.

Die betekenis van hierdie perikope mag nie eensydig gelê word op die wonder van die genesing van 'n besetene nie. Die reaksie by die inwoners van die gebied is net so belangrik. Hulle is naamlik gladnie verheug nie. Hulle skrik oor die onbegryplikheid van wat gebeur en 
is kwaad oor die skade aan hulle varke. Jesus ontsien geen gevestigde reg of orde of besit om een mens te red nie. Dit is 'n skrille kontras met die optrede van die mens; die mens se optrede, ons optrede; nie soos weerspieël in stigtelike toesprake en teologiese verhandelinge nie, maar soos dit blyk uit die werklikheid van daaglikse lewe en verhoudinge. Jesus gee aan God die eer, en vra van die geneesde 'n lewende getuienis.

'n Mens vra jou af: Wie is die mees besetene: Die man wat genees is, of die inwoners wat Jesus vra om hul land te verlaat? Hulle het hierdie abnormale as newe verskynsel van mens-wees aanvaar, as onvermydelikheid. As Jesus die abnormale uit hulle omgewing verban, kan hulle die enigste normale ook maar net vra om hul land te verlaat.

Die goed geklede en wel by sy verstand synde mens van alle tye wil nie weet dat hy 'n slordige en uitsinnige dubbelganger het, tot wie hy nie slegs in 'n verwyderende betrekking staan nie, maar wie se trekke die keersy vorm van sy eie bestaan. Die sogenaamde fatsoenlike mens weet wel dat hy blootstaan aan allerlei invloede wat sy liggaam en gees kan verwar. Maar hy vat dit liefs as versteurdheid op. Figure soos hierdie besetene, wat die tragiek van die lewe weerspieël, word oor die gesigseinder van ons bestaan gestoot. Dit klink middeleeus en word as iets vreemds uit daardie tyd afgemaak. Ons gaan kyk liewer daarna in toneelstukke, maar wil dit nie uit die Bybel hoor nie.

Jesus kom hierheen om te bid. Hy word dit eindelik belet. Let wel: nie deur die demone of die besetene nie, maar deur die gevestigde, wel-toerekenbare mens uit die maatskappy. Kon Jesus hierdie fatsoenlikes nie ook tem nie? Nee. Hy bekeer en oorweldig nie wet-toerekenbare mense teen hulle sin nie; soos $\mathrm{Hy}$ die blindgeborende genees, maar die Fariseërs, wat meen dat hulle sulke skerp oë het, in hulle blindheid laat. Mense kan Jesus uit hulle lewe verban. Dan verlaat Hy dié land. Dit is 'n donker skadu wat oor hierdie geskiedenis val.

Ons kan sê dat besetenheid in hierdie perikope ernstig opgeneem word as menslike moontlikheid. Die vraag bly egter: Het dit tydens Jesus se omwandeling op aarde besonder baie na vore gekom? Of herken ons dit net vandag nie meer nie?

\section{Markus 1:21-32; Lukas 4:33-37}

In die geskiedenis van die genesing van die besetene in Kapérnaüm vind ons baie trekke van die vorige perikope terug. Daar moet onthou word dat die Jode self ook demone uitgedryf het. Hulle het dit volgens so ' $n$ bepaalde skema gedoen: Die demoon bespeur iets in die lug, voel iemand naderkom wat magtiger is as hyself, deurdat hy 
byvoorbeeld in besit is van bepaalde toorformules. Daardeur word hy onrustig en agressief en wil deur middel van 'n vertoning sy mag openbaar. Die besweerder tree hom tegemoet, en met 'n demonstrasie van eie mag deur middel van allerlei toorformules, laat hy die demoon die aftog blaas, tot groot verbasing van die toeskouers.

Soos elders in die Skrif word hier ook van die bekende skema gebruik gemaak. Die inhoud verskil egter radikaal. Daarom is die ontmitologisering van die Skrif deur die teologie ' $n$ dwase onderneming. Want in die Skrif self is dit al klaar gedoen. Die skema word gebruik. By Jesus is egter geen sprake van besweringsformules of hekserye nie. Jesus oorwin deur sy sobere, eenvoudige magswoord. Dis voldoende. Vandaar juis die allesoortreffende verbasing: wie is Hy tog? Hy maak nie van toorformules gebruik nie. Hy gebied, en demone gehoorsaam.

Letterlik staan daar: Die man het 'n gees (of asem) van'n demoon. Dit is harde werklikheid, en herinner aan Openbaring 16:13, 14. Ook hier staan eintlik: Die mens in 'n onreine gees, nie'n demoon in die mens nie. Die gedagte is dat die demone op 'n mens beslag lê, hom gebruik as werktuig en spreekbuis. (Vergelyk hierteenoor Paulus se uitspraak in II Korintiërs 5:77, oor die gelowige "in Christus").

Ook hierdie perikope vertel van twee wêrelde wat op mekaar bots: Die ryk van Satan en die ryk van Christus. Hierdie besetene se hele persoonlikheid het in die boeie van 'n duistere mag geraak. Hy praat nie van "ek" of "my" nie, maar van "ons". Sy gevoel van ek-heid, indiwidualiteit, eie persoonlikheid, het heeltemal verdwyn. Wat uit die optrede van Jesus blyk, is dat Hy absoluut spreek en handel as gevolmagtigde van God, maghebbende.

\section{Lukas 11:14-26; Matteus 12:22-30 en 43-45}

Hier het Jesus verklaar dat Hy nie deur die owerste van die duiwels, duiwels uitdryf nie, maar deur die Gees van God. Met "woning" word bedoel die mens wat genees is. Die voorstelling het in die Ooste geheers dat die demone buitengewoon ongelukkig is sonder woning in mens of dier. So lê hulle altyd op loer om hulle ou woning weer in te dring. So word besetenheid hier gebruik as beeld van die ou mag van die sonde wat so maklik die sondaar met sy skuldige verlede weer tot ' $n$ val bring. Dit gebeur maklik as 'n mens gereinig word maar leeg bly. ' $n$ Besetene was 'n mens sonder eie persoonlikheid. En nadat Hy genees is, kan hy slegs, deur Gods Gees geheilig, tot ' $n$ nuwe persoonlikheid kom. Uitdrywing van bose geeste alleen help dus nog nie. In hulle plek moet die Gees van God woning maak. $\mathrm{Na}$ aanleiding van hierdie Skrifgedeelte het Dr O Noordmans gesê: Die ontmitologisering van die Skrif toon pragtig aan hoe in die plek 
van een duiwel wat uitgedryf word sewe ander kan kom. En hy het daaraan toegevoeg dat romanskrywers dit blykbaar beter weet as teoloë.

\section{Wat was besetenheid in die Nuwe Testament?}

Die opvatting dat besetenheid 'n spesifieke kwaal is wat net tydens Christus se omwandeling op die aarde voorgekom het, is nie vol te hou nie. Daar word dan aangevoer dat juis toe God sy mag en waarheid in Jesus Christus op aarde openbaar, ook die ryk van die demone in volle krag tot openbaring gekom het.

Maar dit staan glad nie vas dat besetenheid destyds wel so veelvuldig voorgekom het nie. Onder 'n groot getal genesings wat gemeld word, lees ons van slegs enkele gevalle van besetenheid. Die evangelie van Johannes meld geen enkele geval van besetenheid nie.

Dit is nie verantwoordbaar om te beweer dat besetenheid in die tyd van die Ou Testament nie voorgekom het nie. Sou koning Saul byvoorbeeld nie in die Nuwe-Testamentiese tyd as sodanig beskryf word nie? In die Nuwe Testament soek die mense genesing by Jesus. Daarom hoor ons so baie van siekes en siektes. In die Ou Testament was al die siekes ook daar, maar ons hoor nie van hulle nie, omdat hulle nie op die voorgrond tree by die dade van die konings nie. Die geloof in Christus word so graag en maklik gemaak tot wonderdoenery. As ons diep daaroor nadink, het Jesus eintlik min wonders gedoen. Hy was daarmee spaarsaam. Die feit dat Hy so min wonders gedoen het, is haas ' $n$ groter wonder as die wonders wat $\mathrm{Hy}$ wel gedoen het.

'n Ander verklaring wat al gegee is, is dat ons hier te doen het met volksgeloof uit die Ooste wat alles wat vir die mens se verstand onverklaarbaar is, toeskryf aan die mag van bose geeste. Dit is waar dat hierdie bygeloof hom selfs tot op die huidige dag in Palestina gehandhaaf het. Ons lees van waterdemone, boomdemone, huisdemone, ensovoorts. Liggaamlike swakheid en siekte word altyd aan sulke demone en hulle vors toegeskryf. ' $n$ Kinderlose word byvoorbeeld ' $n$ "deur domone gebondene" genoem. Dat epilepsie so ongeneeslik is, word toegeskryf aan die feit dat die demoon wat hierdie aanvalle teweegbring, geweldig sterk is. Die Arabiese uitdrukking vir kranksinnig is byvoorbeeld "deur demone bewoon". Soms pak vele (legio!) bose geeste ' $n$ mens tegelyk. Dan word so iemand rasend-wild en 'n gevaar vir die samelewing. Selfs volgens huidige Arabiese opvattings kan iemand deur onversigtige optrede lewenslank in die mag van demone raak: Deur byvoorbeeld as kind op 'n graf te speel. In die lig van bostaande is dit eintlik snaaks dat alle siekes in die Nuwe Testament nie as besetenes aangedui word nie. 
Die feit is egter dat besetenheid wel deeglik van ander siektes onderskei word.

Albei hierdie opvattings moet dus afgewys word naamlik: (1) Dat besetenheid iets was wat slegs destyds voorgekom het as 'n spesifiek-palestynse epidemie. (2) Dat besetenheid net iets was wat volgens volksgeloof vir 'n raaiselagtige siekte gegee was.

Onder besetenheid kan en moet ons liewer dink aan 'n verbysterende en smartlike versteurdheid vanweë die sonde, waar daar van die oorspronklike persoonlikheid haas niks meer oorgebly het nie; in so 'n mate dat dit wou voorkom of die liggaam van so 'n mens, in plaas van daardie oorspronklike siel, deur'n geheimsinnige duistere mag, vreemd aan die natuur van so 'n mens, bewoon was; sodat die deur God-gewilde harmonie tussen siel en liggaam op afgryslike wyse versteur was. Dit was destyds en is nou nog 'n gevolg van die sonde, die werk van die duiwel. Van hierdie duistere dwang het Christus die mens kom bevry. Dit is die hoofsaak. Bysaak is of ons dit aanskouliker probeer voorstel vir ons tyd om te praat van (in moderne terme) swaar histerie, waanvoorstellinge, epilepsie of wat ookal. Dan word die demone-uitdrywery van die Jode (want dit het destyds wydverspreid voorgekom) verklaar as suggestiewe inwerking op die pasiënt. ' $n$ Feit is dat ons die ou terme met nuwes kan vervang. Die saak bly dieselfde.

Daar moet ook nie gedink word dat die besetenes maar net psigies-versteurdes was nie. Christus het ook ander siektes, wat slegs die liggaam aangetas het, toegeskryf aan die mag van Satan; so byvoorbeeld in Lukas 13:16. Hier is sprake van 'n suiwer liggaamsgebrek, naamlik 'n verkromde ruggraat. Ook in al die liggaamlike leed, wat die mens verhinder om sy eie, volle persoonlikheid te ontwikkel, sien Christus die werk van Satan, wat die ryk van God wil teëhou.

\section{Kom hierdie verskynsels vandag nog voor?}

As iewers versigtigheid geëis word, is dit hier, om naamlik nie na links of regs van die smal pad af te gly nie. Enersyds moet ons nie te veel hang aan die letter van hierdie besetenheid en uitdrywery nie. Die Bybel is nou eenmaal geskryf in ' $n$ bepaalde mensetaal, naamlik die wat destyds deur die volk in dié land gepraat is. En net soos Jesus Aramees gepraat het om Homself verstaanbaar te maak, en nie een van ons moderne tale nie, net so seker kon Hy ook sekere siektebeelde nie aandui met vir dié tyd onbegryplike en onmoontlike uitdrukkings soos histerie of epilepsie of wat ookal nie, maar volgens taal en trant van destyds nie anders kon as om te praat van besetenheid nie.

Daarom is dit nie korrek om as gevolg van Bybelse verhale, duiwels op dieselfde wyse te wil uitdryf nie. Daar is dinge wat spesifiek 
net vir die apostels, as oor- en ooggetuies van Christus se werk gegeld het. Om Jesus te volg, beteken nie om die metodes van destyds net so toe te pas nie. Ons lê die Gees van God aan bande ook as ons sê Hy moet nou nog op dieselfde wyse werk as in die 1ste eeu. Dit is tog so dat God vir besondere tye besondere gawes gee. As wat destyds gebeur het, nou nog net so moes gebeur, sou Handelinge en die briewe baie meer daaroor sê. Die boek Handelinge sê egter eerder: So het dit gebeur, as: So moet dit altyd gebeur. So 'n duidelike aanwysing het ons wel oor die doop en nagmaal, maar nie oor duiweluitdrywery nie.

Beheptheid met duiweluitdrywery is dikwels 'n teken van psigopatiese geneigdheid. Duiweluitdrywers is dikwels liggelowige mense. Nie alle tekens en wonders is werk van die Heilige Gees nie. Soos aangedui, kom verskynsels soos hierdie ook buite die Christendom voor, en mag daarom nie tot teken van die werk van die Heilige Gees gemaak word nie. Dit kan ook werk van die menslike psige wees. Die werk van God se Gees en die mens se gees moenie vermeng word nie. Dan ontwikkel praktyke soos duiweluitdrywery baie maklik in 'n psigologiese tegniek, gepaardgaande met dweepsieke gewelddadighede of magiese besweringe. As dit tussen jou en God volkome reg is, kan jy werklik oor die duiwelse magte heers, en sal hulle jou gehoorsaam. So was dit in volkomenheid egter alleen met Christus. Die kerk en elke Christen se taak is nou om daardie oorwinning van Christus te preek en daarvan te getuig.

Andersyds mag ons nie miskyk dat agter die verskynsels van besetenheid en duiweluitdrywing ' $n$ bedoeling sit wat vir alle tye geld naamlik dat Satan agter al die ellende staan as bewerker daarvan, Satan, wat sy verderwende werk reeds in die paradys begin het; Satan, van wie Christus sy slagoffers ontroof. Daar is waarskynlik nooit 'n gevaarliker leun verkondig as dat al hierdie leed van God kom en louterend werk nie. Dit louter nie; dit verbaster!

Die boek Handelinge staan ook in die Bybel om ons daarvan te deurdring dat die Messiaanse werk voortgaan na Christus se dood, en dat die gemeente met die oog daarop begiftig is met allerlei gawes. Die gemeente het die Heilige Gees as eerste gawe ontvang, wat die belofte inhou van die uitbetaling van die volledige som. Maar die volledige som is nog nie uitbetaal nie. Daarom, geen vooruitgryping asof die koninkryk al in sy volheid geopenbaar is nie. Maar ook: Geen bewering dat die gawes uit Handelinge net vir die begintyd van die Christendom daar was nie. Daarmee doen ons ernstig tekort aan die moontlikhede van die Heilige Gees in ons tyd. Daarmee beskuldig ons die Heilige Gees van onmag, wat eintlik niks anders is as ons onwil om vir sy werk ruim baan te maak nie. Deur die Heilige Gees is Christus nou nog teenwoordig in die wêreld en in 
staat en bereid om sy groot werk te manifesteer. Dit wil nie sê dat Hy op dieselfde wyse moet werk as destyds nie. As sy gemeente egter bereid is om die Heilige Gees sy werk te laat doen, sal hulle die werke doen wat Christus gedoen het, en groter selfs as dit (Joh 14:12). Meen ons werklik dat ons tyd minder behoefte aan sulke openbaringe het as die begintyd? Staan ons werklik tans teenoor minder sterk demoniese magte as destyds? Meen ons werklik dat die heidendom van nou minder aggresief is as die van destyds? Is die mens se angs miskien nou minder as destyds? Is die heerskappy van die magte van die duisternis nou minder geweldig as in die jaar $50 \mathrm{n} \mathrm{C}$ ?

Dit gaan om 'n prinsipiële vraag: Neem ons die werklikheid van die sonde, van die sataniese mag, van die Satan aan? En wat sê ons van Christus? Meen ons Hy het gekom om terapie en psigologie te doseer of om die werk van die duiwel te verbreek? Wie by sowel die duiwel, en sy werk, as die verbreking daarvan 'n vraagteken plaas, kan wel met 'n negatiewe antwoord die saak spoedig afmaak. Volgens die evangelie het Jesus egter geglo aan die bestaan van die duiwel, aan besetenheid, en was Hy daarvan bewus dat Hy daaruit kan red.

\section{Besetenheid en duiweluitdrywery as werkwyse van die Charismatiese beweging}

As teenreaksie teen die dwaling van duiweluitdrywers moet die kerk oppas om nie die normale vervul wees met die Heilige Gees verdag voor te stel nie. Die kerk het nog altyd ernstig gefouteer as hy nie die protes teen verwêreldliking en vervlakking in die geloof, by bewegings soos hierdie kon bemerk en ernstig neem nie. Die eerste woord van reaksie van die kerk mag nie afkeur of kritiek wees nie, maar beskaming dat dwalinge soos hierdie (die ding in sy ekstreme vorm) kan opkom mede deurdat die kerk so weinig betoon van gees of krag was (I Kor 2:4). Daarnaas moet ons erken dat sodoende 'n verontagsaamde en verwronge stuk van die evangelie - en tog 'n hartstuk weer aan die orde gestel is naamlik die werk van die Heilige Gees.

Die Reformasie het die geheim van waaragtige en gehoorsame kerkwees opnuut gesien as die handhawing van die geheim van die eenheid van Woord en Gees. Ongelukkig is die behoefte aan sterk belewenis soms sterker as die gehoorsaamheid om na die hele Skrif te luister. Dan word tekste wat handel oor die sigbare tekens van die Heilige Gees se werk oorbeklemtoon, en word Christus later heeltemal verdring. Dan word die heil gebou op subjektiewe ervaringe en nie meer objektief op die volbragte werk aan Christus nie. Ook 'n teken van die werk van die Heilige Gees is dat Hy ons almeer oortuig van ons eie onwaardigheid en sterker op Christus laat vertrou - nie alle wonders wat gebeur werk van die Heilige Gees is nie. Die 
enigste toets is: Word Christus daardeur verheerlik of die mens?

Alle pinkstergroepe van alle tye het te min oog gehad vir die rustige en verborge werk van die Heilige Gees, soos deur eeue se kerkgeskiedenis blyk; ook te min oog vir wat die Heilige Gees nou nog in die ampsdraers werk aan trou en volharding in take wat nie altyd opsien baar nie.

Die pinkstermens het nie genoeg aan die regverdiging deur die geloof alleen nie. Hy soek na iets meer om die heil op te fundeer. So word vele charisma tot ' $n$ nuwe wet waaraan die mens moet voldoen om gered te word. Dan word sulke verskynsels soos duiweluitdrywery geforseer, en daar word neergesien op die agtergeblewe kerkmens wat hierdie besondere manifestasies nie kan aantoon nie.

Daar moet dus ten opsigte van die werk van die Heilige Gees nie geforseer word nie; ook nie voor die tyd uitgesluit word nie. Wil ons opgewasse bly teen die magte van ons tyd is selfs' $n$ diepere verandering nodig as wat die Reformasie in die 16e eeu gebring het. Die Christendom is egter ' $n$ godsdiens van die Woord; nie van bonatuurlike verskynsels nie, en daarom moet elke strewe na vernuwing gerig wees op die suiwere verkondiging van die Woord en om gehoorsaamheid aan daardie Woord te leer. Die Heilige Gees verheerlik Christus en leer ons om Christus en die Woord lief te hê.

Die sug en verlange na vervuldheid met die Heilige Gees behoort die daaglikse inhoud van die kerk se lewe en werk te wees. Paulus het die vervulling met die Heilige Gees as die normale toestand van die gemeente van Jesus Christus beskou. Dan is daar nie plek vir dwaling en allerlei uiterstes nie. Hierdie verlange en gebed beteken nooit 'n nuwe uitstorting van die Heilige Gees nie. Want die Heilige Gees is op Pinksterdag in volheid aan die kerk gegee; nie aan indiwidue in die eerste plek nie, maar aan die kerk. Daarom is die vraag meer korrek gestel: Hoe kan ons die skat wat aan die kerk toevertrou is, gebruik soos dit hoort? Ons moet, soos by die Reformatore, sonder skroom en vrees vir geesdrywery kom tot 'n Bybelse beskouing, in praktyk en besinning, oor die wese en werk van die Heilige Gees.

$\mathrm{Na}$ alles is dit Christus self wat verlangend uitsien daarna dat die wat Hy so duur gekoop het, alle vertroue op menslike sekerhede en hulleself sal laat vaar, en alleen sal vertrou op Hom en die vervulling met sy Heilige Gees. 